\title{
Vagal Control of Satiety and Hormonal Regulation of Appetite
}

\author{
Chung Owyang* and Andrea Heldsinger \\ Division of Gastroenterology, Department of Internal Medicine, University of Michigan, Ann Arbor, Michigan, USA
}

The paradigm for the control of feeding behavior has changed significantly. In this review, we present evidence that the separation of function in which cholecystokinin (CCK) controls short-term food intake and leptin regulate long-term eating behavior and body weight become less clear. In addition to the hypothalamus, the vagus nerve is critically involved in the control of feeding by transmitting signals arising from the upper gut to the nucleus of the solitary tract. Among the peripheral mediators, CCK is the key peptide involved in generating the satiety signal via the vagus. Leptin receptors have also been identified in the vagus nerve. Studies in the rodents clearly indicate that leptin and CCK interact synergistically to induce short-term inhibition of food intake and long-term reduction of body weight. The synergistic interaction between vagal CCK-A receptor and leptin is mediated by the phosphorylation of signal transducer and activator of transcription3 (STAT3), which in turn, activates closure of $\mathrm{K}^{+}$channels, leading to membrane depolarization and neuronal firing. This involves the interaction between CCK/ SRC/phosphoinositide 3-kinase cascades and leptin/Janus kinase-2/phosphoinositide 3-kinase/STAT3 signaling pathways. It is conceivable that malfunctioning of these signaling molecules may result in eating disorders.

\section{(J Neurogastroenterol Motil 2011;17:338-348)}

Key Words

Cholecystokinin; Leptin; Nodose ganglion; Signal transduction

\section{Introduction}

Regulation of feeding behavior is complex. The system integrates hormonal (CCK, ghrelin, insulin and PY3-36 etc), nutrient (glucose and lipids) and neural signals triggered by food ingestion and absorption and receives cues derived from fat (leptin and adiponectin) to inform the hypothalamus about stored energy levels. ${ }^{1}$ Traditionally, attributed to the CNS, the sensing of these signals is now recognized to be mediated at least partially by peripheral systems outside of the melanocortin neuronal circuit of the hypothalamus. ${ }^{1}$ These peripheral signals are relayed via the vagal afferent pathways to the lateral hypothalamus which integrates the various signals and regulates feeding behavior, nutrients, metabolism and energy homeostasis. ${ }^{2-5}$

Cholecystokinin $(\mathrm{CCK})$ is the first gut peptide implicated in the control of food intake. ${ }^{6,7}$ Reduction of food intake following the administration of intestinal mucosal extracts were reported as early as $1937 .{ }^{6}$ In 1973, Gibbs and colleagues ${ }^{7}$ showed that both semi-purified porcine CCK and synthetic CCK octapeptide reduced feeding in rats. Over the last 30 years, numerous studies have provided compelling evidence that $\mathrm{CCK}$ participates in the

Received: August 11, 2011 Revised: September 10, 2011 Accepted: September 15, 2011

(c) This is an Open Access article distributed under the terms of the Creative Commons Attribution Non-Commercial License (http://creativecommons. org/licenses/by-nc/3.0) which permits unrestricted non-commercial use, distribution, and reproduction in any medium, provided the original work is properly cited.

*Correspondence: Chung Owyang, MD

Division of Gastroenterology, Department of Internal Medicine, University of Michigan, 3912 Taubman Center, SPC 5362, $1500 \mathrm{E}$. Medical Center Drive, Ann Arbor, MI 48109, USA

Tel: +1-734-936-4785, Fax: +1-734-936-7392, E-mail: cowyang@med.umich.edu

Financial support: This work was supported by the National Institute of Diabetes and Digestive Kidney Diseases Grants (DK 48415 and DK 34933 ). Conflicts of interest: None. 
control of meal size. ${ }^{8}$ Research has uncovered the neural pathways which mediate CCK's action to induce satiation. ${ }^{9}$

Of the hormones controlling energy balance, leptin plays a central role. ${ }^{10}$ Leptin which is secreted by the adipose tissue at levels proportional to fat content, communicates the repletion of peripheral energy stores to the brain, suppressing feeding and promoting energy expenditure through a number of neuroendocrine and anatomic mechanisms. ${ }^{10}$ In addition to acting directly on the hypothalamic neurons to coordinate behavioral and metabolic controls of energy, leptin may also act on vagal afferent pathways to mediate long-term satiety control. ${ }^{11-13}$ This action is enhanced through a synergistic interaction between leptin and $\mathrm{CCK}$ at the level of the vagal nodose ganglia to reduce short-term food intake in rodents. ${ }^{13,14}$ In this manner, leptin, by interacting with CCK, becomes a major mediator to control short-term food intake and a regulator for long-term feeding behavior and body weight homeostasis.

In this review, we will examine evidence for CCK's participation in the control of meal size and review the neural mechanisms by which CCK reduces food intake. Furthermore, we will summarize the current status of research on leptin receptor signaling and the regulation of eating behavior and energy balance. In vivo and in vitro evidence for synergistic interaction between CCK and leptin at the level of the nodose ganglia will be presented and the intracellular mechanism by which CCK interacts with leptin to enhance signal transducer and activator of transcription 3 (STAT3) signaling regulating feeding will be reviewed.

\section{Cholecystokinin As a Satiety Factor}

$\mathrm{CCK}$ is secreted from small intestinal I cells ${ }^{15,16}$ in response to food ingestion and function as a postprandial satiety signal. ${ }^{17-20}$ The satiety action of CCK was suggested by a number of early studies dating as far back as 1937 when it was shown that systemic injection of duodenal extracts, which probably contained some CCK, reduced food intake in experimental animals. ${ }^{21}$ In 1973, Gibbs and colleagues ${ }^{22}$ reported that i.p. administration of synthetic sulphated CCK-8 significantly reduced the intake of both solid and liquid foods without causing aversive behavior to the rats. Subsequent studies have confirmed that systemic administration of CCK inhibits food intake in a number of other species including pig, dog, monkey, domestic fowl, mouse, sheep, rabbit, hamster and man, ${ }^{23}$ providing further credence to the hypothesis that peripheral CCK acts as a satiety signal. As CCK cannot pen- etrate the blood brain barrier, ${ }^{24}$ it is likely that systemically administered CCK acts at a peripheral site to inhibit feeding. Subsequent studies showed that vagal afferent fibers are responsible for transmitting the peripheral CCK signal to the CNS to mediate satiety. ${ }^{25,26}$ This satiety action is mediated by gastric vagal afferents and involves CCK-A but not CCK-B receptors. ${ }^{27,28}$

A major criticism of the CCK-satiety hypothesis is that the doses of CCK-8 used in some of these earlier studies are many-fold greater than the physiological plasma concentrations that are present following a meal. ${ }^{23}$ Several investigators reported that administration of lower doses of CCK had no effect on satiety. For example Melville et $\mathrm{al}^{29}$ showed that injection of CCK-8 (2-8 $\mu \mathrm{g} / \mathrm{kg})$ directly into the systemic circulation of rats did not affect food intake. Similarly, Ebenezer ${ }^{30}$ found that subcutaneous administration of CCK-8 (5-50 $\mu \mathrm{g} / \mathrm{kg})$ failed to inhibit food intake in rats although doses of CCK-8 as low as 1 $\mu \mathrm{g} / \mathrm{kg}$ s.c. stimulated pancreatic secretion. These observations, however, were not substantiated by other investigators. Covasa and colleagues ${ }^{31}$ reported that intraperitoneal administration of $\mathrm{CCK}$ at a dose as low as $0.5 \mu \mathrm{g} / \mathrm{kg}$ produced physiological plasma CCK levels and significantly decreased food intake in rats. This discrepancy may be related to experimental design and the test meals used in the different studies.

Conclusive evidence that $\mathrm{CCK}$ plays an important role in satiety comes from CCK antagonists studies. A number of animal studies indicate that the inhibitory effects of exogenous peripheral CCK on food intake can be completely abolished by pretreatment with devazepide. ${ }^{32-35}$ These findings suggest that a peripheral CCK-A receptor mechanism is involved in the suppression of feeding produced by CCK. Furthermore, it was found that devazepide on its own increased the size of a test meal when administered systemically to several species including the rat, pig, mouse, monkey, dog, cat and chicken under a number of different feeding schedules and dietary conditions. ${ }^{32,33,35-38}$ These experiments give the first clear-cut indication that endogenous CCK acting via CCK-A receptors plays an important role in the control of food intake.

\section{Structural and Functional Evidence That Cholecystokinin Acts on Vagal Afferent Fibers}

$\mathrm{CCK}$ receptors have been detected in the rat vagus nerve using in vitro receptor autoradiography. ${ }^{39}$ Nerve ligation experiments have shown that these receptors are transported toward the 
peripheral nerve endings from the nodose ganglion. ${ }^{39} \mathrm{CCK}$ binding and axonal transport are evident in all abdominal vagal branches. ${ }^{40}$ The CCK receptors are predominantly type $\mathrm{A}^{40}$ because the CCK-A receptor antagonist L-364718 completely abolishes ${ }^{125}$ I-CCK binding, and nonsulfated CCK has no effect.

Electrophysiologic studies in rats and ferrets have provided evidence that CCK stimulates vagal afferent pathways. ${ }^{41,42} \mathrm{Li}$ et $\mathrm{al}^{41}$ recorded the unitary activities of sensory vagal neurons using microelectrodes implanted in rat nodose ganglia. CCK infusion at $40 \mathrm{pmol} \cdot \mathrm{kg}^{-1} \cdot \mathrm{hr}^{-1}$, which mimics postprandial levels, evoked a marked increase in discharge over basal. ${ }^{41}$ A short latency, slow adaptation and rapid return to basal on removal of the stimulus characterized the response. Similar studies in ferrets showed that mucosal vagal afferent fibers from the duodenum are highly sensitive to CCK-8. ${ }^{42}$ These electrophysiologic studies together with receptor autoradiography studies provide functional and structural evidence that CCK acts on vagal afferent pathways.

\section{Satiety Action of Cholecystokinin Is Mediated by Low-Affinity Cholecystokinin-A Receptor on the Vagus Nerve}

CCK has been shown to interact with 2 affinity states of CCK-A receptor. ${ }^{43,44}$ One site is characterized by high affinity and low capacity and the other, a low affinity and high capacity for CCK. It is not known whether these 2 sites represent distinct proteins or different affinity states of the same receptor protein.

Electrophysiologic evidence for high- and low-affinity vagal CCK-A receptors comes from studies that involve the recording of single-unit discharges of sensory neurons from the nodose ganglia that supply the gastrointestinal tract. ${ }^{45}$ The CCK analog CCK-JMV-180, which acts as an agonist on high-affinity CCK-A receptors and as an antagonist on low-affinity CCK-A receptors, was used to identify the vagal CCK receptor affinity states involved in the mediation of the vagal afferent response to the endogenously released CCK evoked by the diversion of bile-pancreatic juice in rats. ${ }^{45}$ Seven of 32 units were stimulated by the bile-pancreatic juice diversion. The responses were abolished by acute subdiaphragmaticvagotomy or perivagal capsaicin treatment. Infusion of CCK-JMV-180 completely blocked the vagal afferent response to the diversion of bile-pancreatic juice in 3 of 8 neurons tested and had no effect on the response in the remaining 5. Gastric, celiac and hepatic branch vagotomy each abolished the response in different subgroups of neurons. These studies dem- onstrate the presence of both high- and low-affinity CCK-A receptors on distinct vagal afferent fibers.

To identify the vagal CCK receptor affinity site involved in the mediation of satiety, Weatherford et $\mathrm{al}^{46}$ demonstrated that CCK-JMV-180 dose dependently reversed the effect of CCK-8 on satiety. This suggests that the anorexic activity of CCK is mediated through interaction with the low affinity $\mathrm{CCK}$ receptor. Schwartz et $\mathrm{al}^{47}$ reported that CCK-JMV-180 also completely blocked the gastric mechanosensitive vagal afferent response to arterial infusion of CCK-8, which suggests that low affinity CCK receptors also mediate this response. In contrast, Li et al ${ }^{48} \mathrm{dem}-$ onstrated that JMV-180 dose dependently stimulated pancreatic enzyme secretion in rats. This was blocked by perivagal application of capsaicin. Furthermore, in conscious rats, CCK-JMV180 enhanced rather than inhibited pancreatic protein secretion in response to intraduodenal administration of $18 \%$ casein, which has been shown to release endogenous CCK. ${ }^{48}$ These observations indicate that both exogenous and endogenous CCK evoke pancreatic secretion by acting on high affinity CCK receptors. Hence, vagal CCK-A receptors clearly exist in different affinity states and mediate different digestive functions. The satiety action of CCK is mediated by low affinity vagal CCK-A receptors whereas pancreatic enzyme secretion is mediated via high affinity receptors.

\section{Interaction Between Ghrelin and Cholecystokinin on Vagal Control of Satiety}

In addition to $\mathrm{CCK}-\mathrm{A}$ receptors, vagal afferent neurons also express the leptin receptor $(\mathrm{Ob}-\mathrm{R})^{49}$ and receptors associated with stimulation of food intake including the ghrelin (GHS-1), ${ }^{50}$ cannabinoid $(\mathrm{CB} 1){ }^{51}$ orexin $(\mathrm{OX}-\mathrm{R} 1)^{52}$ and melanin-concentrating hormone $(\mathrm{MCH}-1)^{53}$ receptors. Among these, ghrelin and orexin $\mathrm{A}$ inhibit the discharge of vagal afferent neurons in response to $\mathrm{CCK}^{52,54}$ Feeding studies demonstrated that the anorexic effect of $\mathrm{CCK}$ was blocked by pre-administration of ghrelin in rats. Conversely, pretreatment with $\mathrm{CCK}$ inhibited the orexigenic effect of ghrelin. Since CCK-A and ghrelin receptors are colocalized in the nodose ganglia neurons, ${ }^{54}$ it is conceivable that CCK and ghrelin may interfere with signal transmission generated by one another. Recently, it was demonstrated that ghrelin inhibited the effect of CCK at least in part through control of the nuclear localization of phosphorylated cAMP response elementbinding protein. ${ }^{55}$ Thus, it appears that the efficiency of ghrelin 
or CCK to modulate feeding behavior may depend on the balance of plasma concentrations of these hormones. Together these observations indicate a sophisticated pattern of integration at the level of vagal afferent neurons to control feeding.

\section{Malfunctioning of Cholecystokinin Receptor Is Associated With Obesity}

Overeating resulting in obesity has been reported in rats with gene mutation preventing normal expression of the CCK-A receptor gene. ${ }^{56,57}$ These rats failed to reduce their food intake in response to $\mathrm{CCK}$ administration. They ingested abnormally large meals and became obese supporting the hypothesis that CCK may participate in long-term regulation of food intake and adiposity in rats.

Obesity has been reported in a patient who expressed fewer functional CCK-A receptors due to defective post-translational processing of receptor protein. ${ }^{58}$ This patient also had cholelithiasis raising the possibility that the association between cholelithiasis and obesity may be related to CCK receptor dysfunction. $^{58,59}$

\section{Leptin Mediates Long-term Satiety and Metabolism}

Leptin, the product of the ob gene, is secreted primarily from white adipose tissue and its level in the circulation correlates with the degree of adiposity. ${ }^{60-62}$ Circulating leptin gains access to the brain via a receptor-mediated transport system ${ }^{63}$ and acts on the long form of the leptin receptor in the medial hypothalamus to regulate feeding behavior and energy balance. ${ }^{10,64}$ Recent studies indicate that leptin is also secreted from the gastric mucosa. ${ }^{65-67}$ Leptin mRNA and leptin protein have been detected in the chief cells of human stomach mucosa ${ }^{67}$ and rat gastric fundic mucosa. ${ }^{66}$ Leptin levels in the stomach are altered by nutritional state and the administration of CCK. Refeeding of fasted rats led to a $66 \%$ decrease in gastric leptin after 15 minutes and a small increase in plasma leptin. ${ }^{66}$ A similar pattern of leptin secretion was seen after intraperitoneal administration of $\mathrm{CCK}$ in fasted rats. However, CCK was not a stimulus for leptin release from isolated adipocytes. ${ }^{66}$ On the other hand, CCK, secretin and pentagastrin stimulate leptin release from gastric endocrine cell. ${ }^{66,67}$ It is conceivable that the postprandial increase in leptin in the circulation originates from the stomach.

Leptin is a key signaling molecule responsible for long-term control of feeding and energy balance. Although ob/ob mice are more sensitive to leptin's effects, reduction of food intake and weight loss can be elicited by repeated peripheral injection of leptin or by adenovirus-mediated leptin gene therapy in lean mice and rats. ${ }^{60,61,68-70}$ By contrast leptin seems not to affect short term alteration of feeding behavior. ${ }^{65,71}$ Kinetic studies indicate that upon a single intravenous or intraperitoneal injection, leptin decreases food intake only after 5-6 hours in ob/ob or lean mice. ${ }^{71,72}$ This may be related to the delayed bioavailability of leptin to reach or influence the target sites of action in the brain. Alternatively, leptin may require the presence of food-related gastric or intestinal signals. In contrast, intraperitoneal CCK induced a reduction in food intake after 15 minutes. ${ }^{73,74}$ Hence, leptin may serve as a long-term regulator of nutrient intake, adiposity, and body weight whereas CCK may act as a meal-related short-term satiety signal.

\section{Molecular and Neural Mediators of Leptin Actions}

Until recently, the satiety and metabolic actions of leptin are believed to be mediated exclusively by the hypothalamus. ${ }^{64}$ As shown in Figure 1, neuroanatomically discrete population of leptin receptor expressing neurons mediate distinct components of leptin action. Clusters of neurons in the lateral, arcuate and ventro-medial hypothalamus play an important role in mediating satiety and glycemic control as well as thyroid and reproductive functions perhaps via indirect connections with other areas. ${ }^{64,75-81}$ The arcuate and ventro-medial hypothalamus are defined as "satiety centers" because lesion of either blunts satiety and promotes hyperphagia and obesity. ${ }^{82,83}$ In these centers, 2 well-characterized populations of neurons express leptin receptor: one population synthesizes the orexigenic neuropeptide Y (NPY), the other neural population synthesizes the anorexigenic pro-hormone pro-opiomelanocortin (POMC). ${ }^{75,84-86}$ Leptin activates/ depolarizes POMC neurons and increases POMC synthesis ${ }^{75,76}$ to decrease appetite and increase energy expenditure by activating CNS melanocortin receptors. ${ }^{87,88}$ At the same time, leptin inhibits NPY/agouti-related protein neuron and suppresses expression of these orexigenic neuropeptide. ${ }^{75,76}$ In this manner leptin signaling stimulates the production of anorectic POMC and suppresses the levels of orexigenic agouti-related protein and NPY.

Recently the function of specific tyrosine residues/signaling pathways of the leptin receptor has been investigated by the generation and study of homologously targeted "knock-in" mice in 


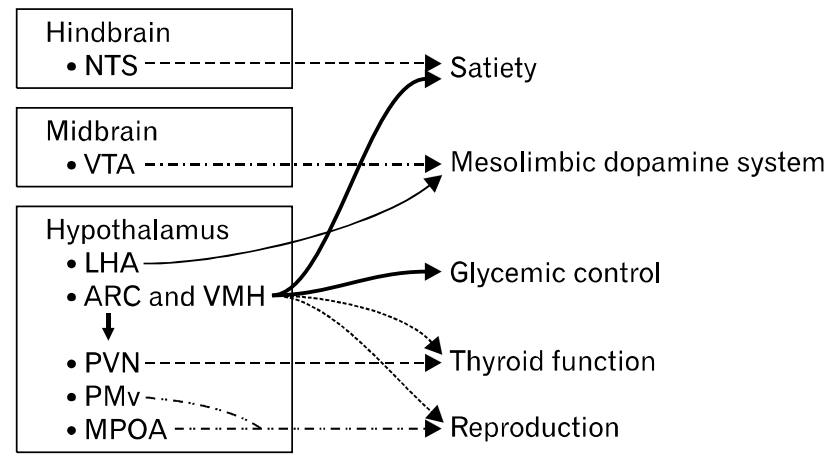

Figure 1. Neuroanatomically discrete populations of leptin receptor expressing neurons mediate distinct components of leptin action. The hypothalamic nuclei, including the arcuate, dorsomedial, ventromedial, lateral hypothalamic area and ventral premammillary (PMv) nuclei play an important role in the regulation of satiety and glycemic control. The hindbrain including the nucleus of the solitary tract which is activated by the vagal afferent pathway may also regulate satiety. In addition, leptin differentially regulates 2 populations of thyrotropin releasing hormoneexpressing neurons in the paraventral nucleus to modulate thyroid hormone secretion via the hypothalamic-pituitary axis. Leptin also acts on neurons in the PMv and medial preoptic area to regulate reproductive function by modulating gonadotropin releasing hormone secretion. NTS, nucleus of the solitary tract; VTA, ventral tegmental area; LHA, lateral hypothalamic area; ARC, arcuate; VMH, ventromedial; PVN, paraventral nucleus; MPOA, medial preoptic area. Modified figure adopted from Robertson et $\mathrm{al}^{64}$ with permission from Elsevier.

which sequences encoding substitution mutants of specific leptin receptor phosphorylation sites replace the endogenous Lepr allele. ${ }^{89,90}$ Through this approach, it was demonstrated that leptin binding to its receptor activates the associated Janus kinase-2 (Jak2) tyrosine kinase to promote the phosphorylation of Jak2 and 3 residues on its leptin receptor; each of these sites mediates a distinct aspect of downstream signaling, with differing physiologic functions (Fig. 2). $\mathrm{Tyr}_{1138} \rightarrow$ STAT3 signaling suppresses feeding but is not required for a number of other leptin actions. ${ }^{91}$ On the other hand, $\mathrm{Tyr}_{985}$ binds $\mathrm{SH} 2$-containing tyrosine phosphatase- 2 and suppressor of cytokine signaling-3 (SOCS3) and primarily mediates the attenuation of leptin receptor signaling via SOCS3. ${ }^{92}$ The role for $\mathrm{Tyr}_{1077}$, the major regulator of STAT5 during leptin signaling, in the physiologic response of leptin remains unclear. ${ }^{10}$

\section{Leptin Regulation of Satiety: The Nodose Ganglia and Hind Brain}

In addition to the hypothalamus, the brainstem, particularly the nucleus of the solitary tract (NTS) and nearby interconnected

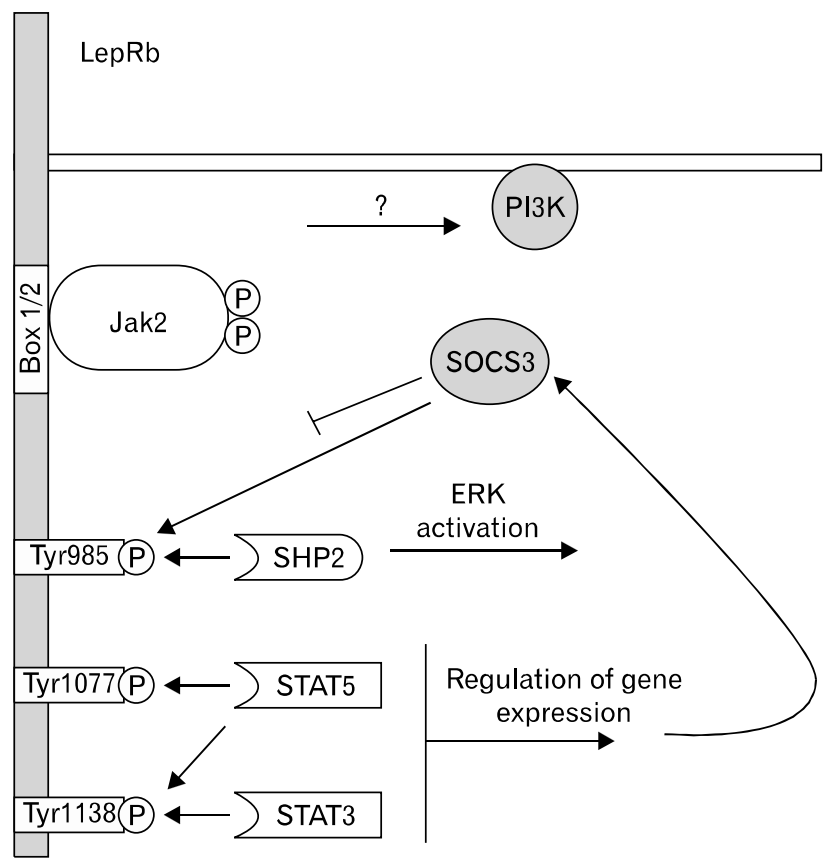

Figure 2. The role of discrete leptin receptor $\mathrm{b}(\mathrm{LepRb})$ functional sites in leptin signaling. Leptin binding to LepRb activates the associated Janus kinase-2 (Jak2) tyrosine kinase bound at the Box1/2 motifs. Activated Jak2 undergoes robust autophosphorylation and phosphorylates $\mathrm{Tyr}_{985}, \mathrm{Tyr}_{1077}$ and $\mathrm{Tyr}_{1138}$ on the LepRb intracellular tail. These phosphorylated residues act as docking sites for SH2-domain containing proteins. Phosphorylated $\mathrm{Tyr}_{985}$ mediates docking with $\mathrm{SH} 2$ domaincontaining tyrosine phosphatase 2 and subsequent activation of extracellular signal-regulated kinase through the mictogen-activated protein kinase signaling cascade. Phosphorylated $\mathrm{Tyr}_{1077}$ mediates signal transducer and activator of transcription 5 (STAT5) activation. Phosphorylated $\mathrm{Tyr}_{1138}$ mediates both STAT3 and STAT5 activation. STAT3 activation ultimately leads to increased expression of suppressor of cytokine signaling-3, which acts as a feedback inhibitor and negatively regulates LepRb signaling in part by binding phosphorylated Tyr985. Leptin also activates phosphoinositide 3-kinase, although the intermediated steps for this process remain obscure. PI3K, phosphoinositide 3-kinase; SOCS3, suppressor of cytokine signaling-3; SHP2, SH2 domain-containing tyrosine phosphatase 2; ERK, extracellular signalregulated kinase. Modified figure adopted from Robertson et a ${ }^{64}$ with permission from Elsevier.

regions ${ }^{83,93}$ also plays an important role in the control of satiety. The NTS receives numerous inputs from the gut via the vagal afferent pathways and relays this information to the hypothalamus satiety and feeding centers. The long form of the leptin receptor (Ob-Rb) has been found in a subpopulation of vagal afferent neurons. ${ }^{79,94-96}$ Using an in vitro gastric vagus-stomach preparation, electrophysiological recording revealed that exogenous leptin alters the firing rate of a subset of vagal afferent fibers and in a 
second group of fibers, leptin failed to activate neural firing but CCK pretreatment increased leptin sensitivity so that the fibers respond to subsequent leptin administration suggesting that there may be a cooperative activation of these fibers by CCK and leptin. ${ }^{97}$ Hence it is conceivable that satiety signals generated by the vagus in response to leptin may be processed in the NTS and relayed to the hypothalamus to regulate eating behavior.

\section{Interaction Between Vagal Cholecystokinin-A and Leptin Receptor -}

Recently the paradigm for control of feeding behavior has changed significantly. The separation of function in which CCK controls short-term food intake and leptin regulates long-term food intake and body weight ${ }^{60-62}$ has become less clear. ${ }^{60-62}$ Rodent studies showed that leptin and CCK interact synergistically to induce short-term inhibition of food intake $e^{13,98}$ and long-term reduction of body weight. ${ }^{99,100}$ It was reported that leptin injected intraperitoneally at low doses $(4-120 \mu \mathrm{g} / \mathrm{kg}$ ), which did not influence feeding behavior for the first 3 hours postinjection, decreased food intake dose dependently by $47 \%-87 \%$ during the first hour when co-injected with a subthreshold dose of CCK. This synergistic effect was shown to be mediated by CCK-A receptors and capsaicin-sensitive vagal fibers. ${ }^{13}$ The decrease in food intake occurring 5 hours after i.p. injection of leptin alone was also blunted by devazepide. In separate studies, it was shown that co-injection of leptin and CCK enhanced the number of fos-positive cells in the hypothalamic paraventricular nucleus by $60 \%$ whereas leptin or CCK alone did not modify fos expression. These observations indicate the existence of a functional synergistic interaction between leptin and CCK leading to early suppression of food intake. In addition the CCK-leptin synergy also may contribute to long-term regulation of body weight. ${ }^{99}$ It was observed that a single i.p. injection of CCK given 2-3 hours after intracerebroventricular leptin $(2-5 \mu \mathrm{g})$ reduced body weight and chow intake over the ensuing $48 \mathrm{hr}$ more than did leptin alone. Subsequently this leptin-CCK interaction was reported to be associated with an increase in firing frequency of gastric vagal terminals ${ }^{97}$ and in neuronal activity in the NTS. ${ }^{98,101}$ Collectively, these data indicate that the mechanisms underlying the interaction of leptin and CCK to induce early suppression of food intake are mediated via the vagus nerve.

To characterize the interaction between CCK and leptin, single neuronal discharges of vagal primary afferent neurons innervating the gastrointestinal tract were recorded from rat nodose
A

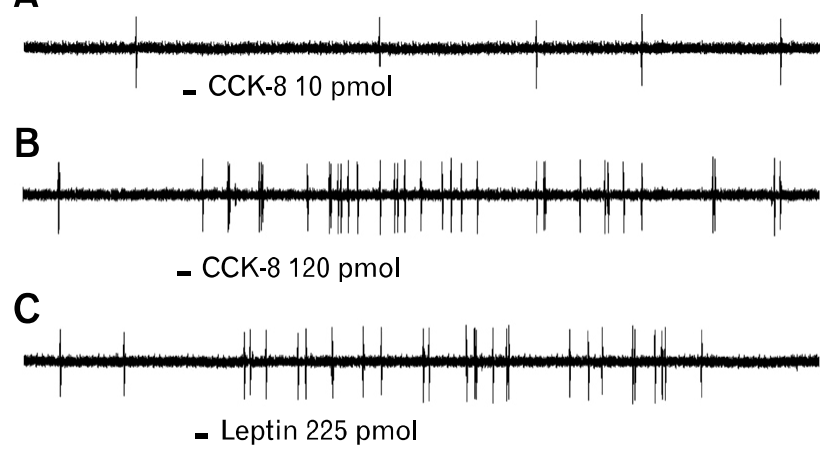

D

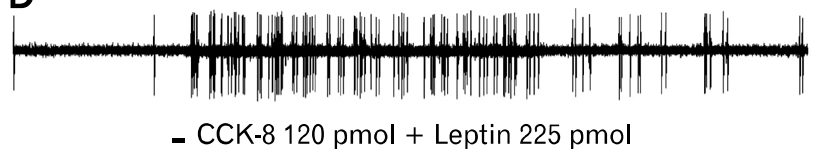

E

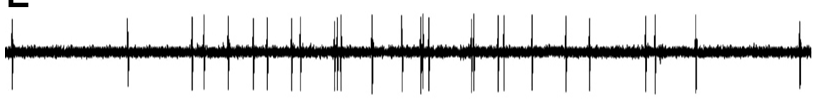

- CCK-8 $120 \mathrm{pmol}+$ Leptin $225 \mathrm{pmol}+$ JMV-180 $5.0 \mu \mathrm{g}$

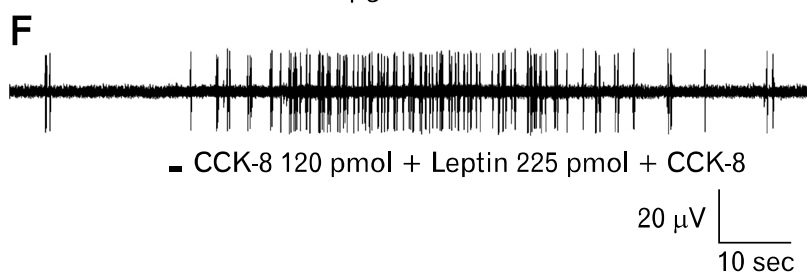

Figure 3. Interaction between cholecystokinin-8 (CCK-8) and leptin on nodose neuronal firing, and the effect of JMV-180 on this interaction. Intraarterial infusion of CCK-8 (10 pmol) (A) did not stimulate vagal nodose neuronal firing. CCK-8 at $120 \mathrm{pmol}$ (B) and leptin at $225 \mathrm{pmol}$ (C) increased the neuronal discharge frequency. (D) A synergistic effect was observed when CCK and leptin were infused together. (E, F) Administration of JMV-180 but not CCK- 8 prevented this potentiation effect, which suggests that low-affinity CCK-A receptors are coexpressed with leptin receptors in rat nodose ganglia. Adapted from Li et al. ${ }^{96}$

ganglia. ${ }^{96}$ Three groups of nodose ganglion neurons were identified: Group 1 responded to CCK but not to leptin, Group 2 responded to leptin but not to $\mathrm{CCK}$ and Group 3 responded to high-dose CCK and leptin. These neurons also showed CCK and leptin potentiation (Fig. 3). Using the CCK-JMV-180, a high affinity CCK-A receptor agonist and low-affinity CCK-A receptor antagonist, it was further demonstrated that low-affinity $\mathrm{CCK}$ receptors are co-expressed with leptin receptors in the rat nodose ganglia. These provide a neurochemical basis for the synergistic interaction between $\mathrm{CCK}$ and leptin to regulate feeding behavior. 


\section{Synergistic Interaction Between Leptin and Cholecystokinin Receptor in the Nodose Ganglia Involves JAK/STAT3, SRC and PI3 Kinase Signaling Pathways}

Recent studies demonstrate that synergistic interaction between CCK and leptin in the nodose ganglia is mediated by cross-talk between signaling cascades used by CCK-A receptor and leptin receptors, which, in turn, activates closure of $\mathrm{K}^{+}$channels, leading to membrane depolarization and neuronal firing. ${ }^{14}$ Patch clamp performed on isolated nodose ganglia neurons showed that combination of leptin and CCK-8 caused a significant increase in membrane input resistance, compared to leptin or CCK-8 alone. A current-voltage relationship analysis showed that the current reversed at $-100 \mathrm{mV}$ for each peptide alone and in combination, which is close to the $\mathrm{K}^{+}$equilibrium potential $(-105 \mathrm{mV})$, suggesting that this depolarization is mediated by $\mathrm{K}^{+}$channels. Silencing the STAT3 gene abolished the synergistic action of leptin/CCK-8 on neuronal firing. It was also demonstrated that leptin/CCK-8 synergistically stimulated a more than 7 fold increase in phosphorylated STAT3, which was inhibited by RhoA inhibitor C3 transferase, the SRC kinase inhibitor PP2 and the phophoinositide 3-kinase (PI3K) inhibitor LY294002. In contrast, the mitogen-activated protein kinase inhibitor PD98059 had no effect. ${ }^{14}$ Furthermore, silencing the SRC and PI3K genes resulted in a loss of leptin/CCK stimulated STAT3. These findings indicate that leptin/CCK-8 synergism involves the interaction between $\mathrm{CCK} / \mathrm{SRC} / \mathrm{PI} 3 \mathrm{~K}$ cascades and the leptin/JAK2/PI3K/STAT3 signaling pathways, with a major role for PI3K (Fig. 4). It is therefore conceivable that malfunctioning of these signaling molecules may result in eating disorders.

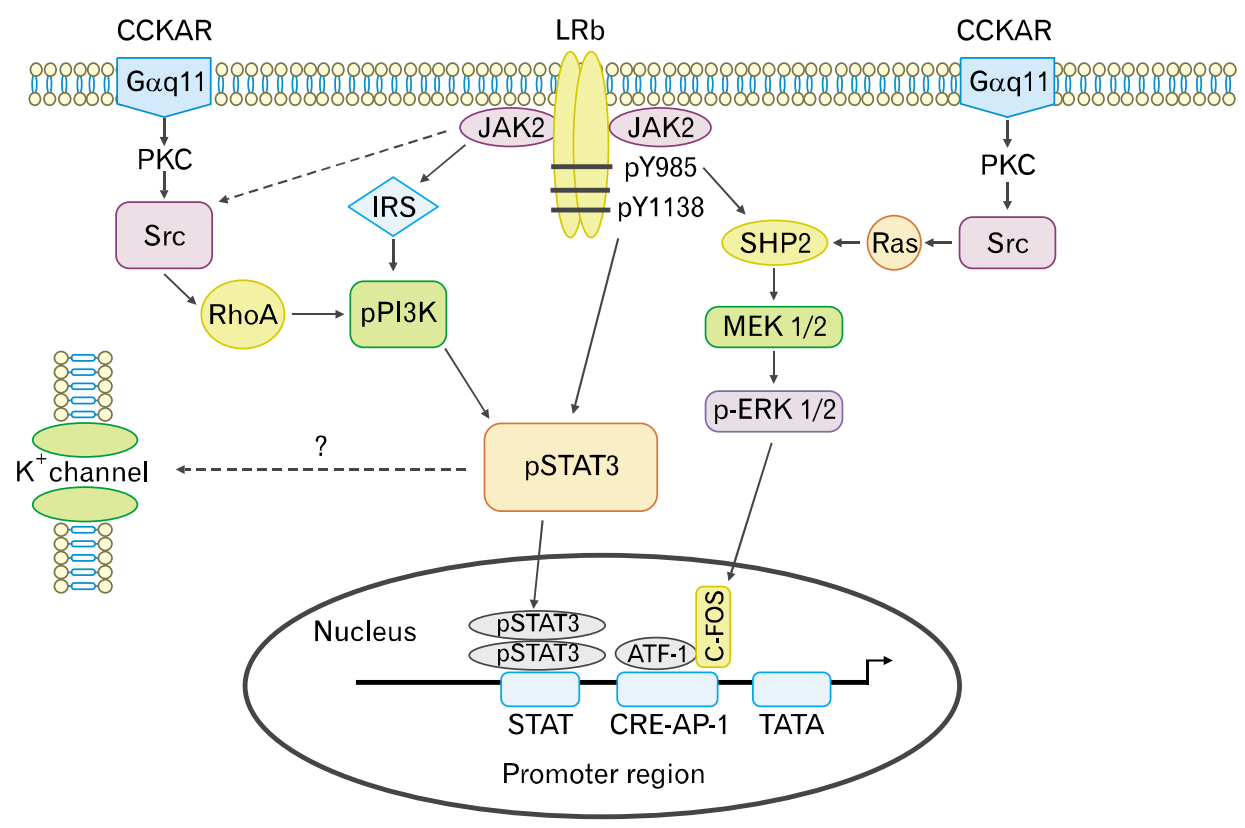

Figure 4. Proposed signal transduction pathways in nodose ganglia following receptor activation with leptin and cholecystokinin-8 (CCK-8). There are 2 potential pathways for phosphorylation of signal transducer and activator of transcription 3 (STAT3). Leptin activates Janus kinase-2 phosphorylation at tyrosine 1138, which directly phosphorylates STAT3, or leptin activates phophoinositide 3-kinase (PI3K) via the insulin receptor substrate, leading to STAT3 phosphorylation. CCK-8 activates PI3K via SRC and RhoA, which leads to phosphorylation of STAT3, suggesting that $\mathrm{PI} 3 \mathrm{~K}$ is central to the synergistic leptin/CCK STAT3 phosphorylation. The mitogen-activated protein kinase (MAPK) inhibitor PD98059 had no effect on leptin and CCK-8 synergism, suggesting that the leptin/CCK-8-stimulated MAPK/ extracellular signal-regulated kinase 1/2 pathway was not involved in STAT3 phosphorylation. STAT3 usually acts by stimulating the transcription of target genes, but the rapid electrophysiological effects suggest STAT3 may be involved in modifying the activity of $\mathrm{K}^{+}$channels. CCKAR, CCK-A receptor; LRb, leptin receptor b; PKC, protein kinase C; JAK2, Janus kinase-2; IRS, insulin receptor substrate; SHP2, SH2 domain-containing tyrosine phosphatase 2; ERK, extracellular signal-regulated kinase; MEK, MAPK/ERK kinase; ATF-1, activating transcription factor-1; CRE, cAMP response element-binding protein; AP-1, activator protein-1. Adapted from Heldsinger et al. ${ }^{14}$ 


\section{Physiological Implications \\ in Regulation of Short-term and Long-term Satiety Control}

The synergistic link between CCK and leptin is strengthened by the observations that the ability of $\mathrm{CCK}$ or leptin signaling to reduce food intake is altered when either factor is blunted or their receptors are non-functional. It was reported that onset of leptin's action to reduce food intake was delayed when food was withheld for $4 \mathrm{hr}$ immediately after i.p. leptin injection in lean mice. ${ }^{13}$ Moreover, i.p. injection of devazepide before refeeding fasted mice interfered with the reduction of food intake normally occurring 5-7 hour after i.p. injection of leptin. ${ }^{13}$ These observations suggest that leptin signaling pathways to the brain are dampened in the absence of interaction with $\mathrm{CCK}$ release after a meal or when CCK-A receptors are blocked. Conversely, both obese $\mathrm{ob} / \mathrm{ob}$ mice which are leptin deficient ${ }^{65}$ and fa/fa Zucker rats which have a missence mutation in the leptin receptor gene are quite insensitive to the meal-terminating effect of peripheral CCK administered at low doses. ${ }^{102-105}$ In addition, CCK antagonists increase meal size in lean but not in obese fa/fa Zucker rats. ${ }^{106}$ These findings are consistent with fa/fa Zucker rats being deficient not only in long-term but also short-term dietary cues related to dysfunctional leptin-CCK potentiating interaction.

\section{Future Directions in Cholecystokinin/Leptin Signaling and Physiology}

The demonstration that synergistic interaction between leptin and CCK occurs in the nodose ganglia has important physiological implications. It provides an explanation for the observation that the ability of CCK or leptin signaling to reduce food intake is altered when either factor is blunted or their receptors are non-functional. It is conceivable that mutation of either leptin or CCK-A receptor or their intracellular signaling molecules may result in eating disorders. Large cohort genetic studies of obese patients to examine these possibilities are warranted.

We demonstrated that the intracellular mechanisms by which CCK interacts with leptin to enhance nodose ganglia excitation involve STAT3 signaling. ${ }^{14}$ STAT3 usually acts by stimulating the transcription of target genes, ${ }^{107}$ but the rapid electrophysiological effects that were observed in a number of studies ${ }^{11,12,14,97}$ are not likely to be explained by STAT3-mediated transcription. It is possible that STAT3 may be involved in modifying the activity of channels or receptors. This interesting phenomenon requires further studies.

The recent demonstration that dietary macronutrient content affects sensitivity to $\mathrm{CCK}$ adds further complexity to the regulation of eating behavior. ${ }^{108-111}$ It was demonstrated that rats on high fat diets exhibit reduced satiety in response to $\mathrm{CCK} .{ }^{108}$ Similarly, leptin resistance develops in vagal afferent neurons of diet-induced obese rats. ${ }^{112}$ This resistance to leptin coincides with attenuation of CCK-induced inhibition of food intake and onset of hyperphagia. It is conceivable that development of resistance to leptin alters CCK signaling resulting in hyperphagia and weight gain. Investigation of the mechanisms by which fatty diet alters the sensitivity of CCK action of satiety control represents an important step in understanding the satiety action of $\mathrm{CCK} /$ leptin to mediate eating behavior and body weight homeostasis.

\section{References}

1. Thorens B. Glucose sensing and the pathogenesis of obesity and type 2 diabetes. Int J Obes 2008;32(suppl 6):S62-S71.

2. Savage LM, Ramos RL. Reward expectation alters learning and memory: the impact of the amygdala on appetite-driven behaviors. Behav Brain Res 2009;198:1-12.

3. German J, Kim F, Schwartz GJ, et al. Hypothalamic leptin signaling regulates hepatic insulin sensitivity via a neurocircuit involving the vagus nerve. Endocrinology 2009;150:4502-4511.

4. Cone RD. Anatomy and regulation of the central melanocortin system. Nat Neurosci 2005;8:571-578.

5. Blouet C, Jo YH, Li X, Schwartz GJ. Mediobasal hypothalamic leucine sensing regulates food intake through activation of a hypothalamus-brainstem circuit. J Neurosci 2009;29:8302-8311.

6. Maclagan NF. The role of appetite in the control of body weight. J Physiol 1937;90:385-394.

7. Gibbs J, Young RC, Smith GP. Cholecystokinin decreases food intake in rats. J Comp Physiol Psychol 1973;84:488-495.

8. Ritter RC, Covasa M, Matson CA. Cholecystokinin: proofs and prospects for involvement in control of food intake and body weight. Neuropeptides 1999;33:387-399.

9. Rogers RC, Hermann GE. Mechanisms of action of CCK to activate central vagal afferent terminals. Peptides 2008;29:1716-1725.

10. Villanueva EC, Myers MG Jr. Leptin receptor signaling and the regulation of mammalian physiology. Int J Obes (Lond) 2008; 32(suppl 7):S8-S12.

11. Peter JH, Karpiel AB, Ritter RC, Simasko SM. Cooperative activation of cultured vagal afferent neurons by leptin and cholecystokinin. Endocrinology 2004;145:3652-3657.

12. Peters JH, Ritter RC, Simasko SM. Leptin and CCK modulate complementary background conductances to depolarize cultured nodose neurons. Am J Physiol Cell Physiol 2006;290:C427-C432.

13. Barrachina MD, Martínez V, Wang L, Wei JY, Taché Y. Syner- 
gistic interaction between leptin and cholecystokinin to reduce short-term food intake in lean mice. Proc Natl Acad Sci USA 1997;94:10455-10460.

14. Heldsinger A, Grabauskas G, Song I, Owyang C. Synergistic interaction between leptin and CCK in the rat nodose ganglia is mediated by PI3 kinase and STAT3 signaling pathways: implications for leptin as a regulator of short-term satiety. J Biol Chem 2011;286: 11707-11715.

15. Buchan AM, Polak JM, Solcia E, Capella C, Hudson D, Pearse AG. Electron immunohistochemical evidence for the human intestinal I cell as the source of CCK. Gut 1978;19:403-407.

16. Polak JM, Bloom SR, Rayford PL, Pearse AG, Buchan AM, Thompson JC. Identification of cholecystokinin-secreting cells. Lancet 1975;2:1016-1018.

17. Lee MC, Schiffman SS, Pappas TN. Role of neuropeptides in the regulation of feeding behavior: a review of cholecystokinin, bombesin, neuropeptide Y, and galanin. Neurosci Biobehav Rev 1994; 18:313-323.

18. Crawley JN, Corwin RL. Biological actions of cholecystokinin. Peptides 1994;15:731-755.

19. Weller A, Smith GP, Gibbs J. Endogenous cholecystokinin reduces feeding in young rats. Science 1990;247:1589-1591.

20. Lewis LD, Williams JA. Regulation of cholecystokinin secretion by food, hormones, and neural pathways in the rat. Am J Physiol 1990;258(4 Pt 1):G512-G518.

21. Maclagan NF. The role of appetite in the control of body weight. J Physiol 1937;90:385-394.

22. Gibbs J, Young RC, Smith GP. Cholecystokinin decreases food intake in rats. J Comp Physiol Psychol 1973;84:488-495.

23. Baldwin BA, Parrott RF, Ebenezer IS. Food for thought: a critique on the hypothesis that endogenous $\mathrm{CCK}$ acts as a physiological satiety factor. Prog Neurobiol 1998;55:477-507.

24. Passaro E Jr, Debas H, Oldendorf W, Yamada T. Rapid appearance of intraventricularly administered neuropeptides in the peripheral circulation. Brain Res 1982;241:355-340.

25. Smith GP, Jerome C, Norgren R. Afferent axons in abdominal vagus mediated satiety effect of CCK in rats. Am J Physiol 1985; 249(5 Pt 2):R638-R641.

26. Ritter RC, Ladenheim EE. Capsaicin pretreatment attenuates suppression of food intake by CCK. Am J Physiol 1985;248(4 Pt 2):R501-R504.

27. Dourish CT, Rucket AC, Tattersall FD, Iversen SD. Evidence that decreased feeding induced by systemic injection of CCK is mediated by CCK-A receptors. Eur J Pharmacol 1989;173:233-234.

28. Smith GP, Jerome C, Cushin BJ, Eterno R, Simansky KJ. Abdominal vagotomy blocks the satiety effects of cholecystokinin in the rat. Science 1981;213:1036-1037.

29. Melville LD, Smith GP, Gibbs J. Devazepide antagonized the inhibitory effect of cholocystokinin in sham-feeding rats. Pharmacol Biochem Behav 1992;43:975-977.

30. Ebenezer IS. The effects of a peripherally acting cholecystokinin1 receptor antagonist on food intake in rats: implications for the cholecystokinin-satiety hypothesis. Eur J Pharmacol 2003;461:113-118.

31. Covasa M, Marcuson JK, Ritter RC. Diminished satiation in rats exposed to elevated levels of endogenous or exogenous cholecystokinin. Am J Physiol Regul Integr Comp Physiol 2001;280:
R331-R337.

32. Hewson G, Leighton GE, Hill RG, Hughes J. The cholecystokinin receptor antagonist $\mathrm{L} 364,718$ increases food intake in the rat by attenuating the action of endogenous cholecystokinin. Br J Pharmacol 1988;93:79-84.

33. Ebenezer IS, de la Riva C, Baldwin BA. Effects of the CCK receptor antagonist MK-329 on food intake in pigs. Phsyiol Behav 1990;47:145-148.

34. Silver AJ, Flood JF, Song AM, Morley JE. Evidence for a physiological role for CCK in the regulation of food intake in mice. Am J Physiol 1989;256(3 Pt 2):R646-R652.

35. Weatherford SC, Chiruzzo FY, Laughton WB. Satiety induced by endogenous and exogenous cholecystokinin is mediated by CCK-A receptors in mice. Am J Physiol 1993;262(4 Pt 2):R574-R578.

36. Covasa M, Forbes JM. Effects of the CCK receptor antagonist MK-329 on food intake in broiler chickens. Pharmacol Biochem Behav 1994;48:479-486.

37. Cheng CA, Geoghegan JG, Lawson DC, Berlangieri SU, Akwari $\mathrm{O}$, Pappas TN. Central and peripheral effects of CCK receptor antagonists on satiety in dogs. Am J Physiol 1993;265(2 Pt 1):G219G223.

38. Bado A, Duriex C, Moizo L, Rogues BP, Lewn MJ. Cholecystokinin-A receptor mediation of food intake in cats. Am J Physiol 1991;256(4 Pt 2):R693-R697.

39. Zarbin MA, Wamsley JK, Innis RB, Kuhar MJ. Cholecystokinin receptors: presence and axonal flow in the rat vagus nerve. Life Sci 1981;29:697-705.

40. Moran TH, Smith GP, Hostetler AM, McHugh PR. Transport of cholecystokinin (CCK) binding sites in subdiaphragmatic vagal branches. Brain Res 1987;415:149-152.

41. Li Y, Zhang XC, Wang LM, Renenan EW, Fogel R, Owyang C. Vagal afferent pathway mediates physiological action of CCK on pancreatic enzyme secretion: pancreatic secretion, neurophysiological and receptor autoradiographic studies. Gastroenterology 1993; 104:A837.

42. Blackshaw LA, Grundy D. Effect of cholecystokinin on two classes of gastroduodenal vagal afferent fibers. J Auton Nerv Syst 1990; 31:191-201.

43. Sankaran H, Goldfine ID, Bailey A, Licko V, Williams JA. Relationship of cholecystokinin receptor binding to regulation of biological functions in pancreatic acini. Am J Physiol 1982;242: G250-G257.

44. Villanueva ML, Collins SM, Jensen RT, Gardner JD. Structural requirements for action of cholecystokinin on enzyme secretion from pancreatic acini. Am J Physiol 1982;242:G416-G422.

45. Li Y, Zhu J, Owyang C. Electrical physiological evidence for high and low-affinity vagal CCK-A receptors. Am J Physiol 1999;277(2 Pt 1):G469-G477.

46. Weatherford SC, Laughton WB, Salabarria J, et al. CCK satiety is differentially mediated by high- and low-affinity CCK receptors in mice and rats. Am J Physiol 1993;264(2 Pt 2):R244-R249.

47. Schwartz GJ, McHugh PR, Moran TH. Pharmacological dissociation of responses to CCK and gastric loads in rat mechanosensitive vagal afferents. Am J Physiol 1994;267(1 Pt 2):R303R308.

48. Li Y, Hao Y, Owyang C. High-affinity CCK-A receptors on the 
vagus nerve mediate CCK-stimulated pancreatic secretion in rats. Am J Physiol 1997;273(3 Pt 1):G679-G685.

49. Burdyga G, Spiller D, Morris R, et al. Expression of the leptin receptor in rat and human nodose ganglion neurons. Neuroscience 2002;109:339-347.

50. Burdyga G, Varro A, Dimaline R, Thompson DG, Dockray GJ. Ghrelin receptors in rat and human nodose ganglia: putative role in regulating $\mathrm{CB}-1$ and $\mathrm{MCH}$ receptor abundance. Am J Physiol Gastrointest Liver Physiol 2006;290:G1289-G1297.

51. Burdyga G, Lal S, Varro A, Dimaline R, Thompson DG, Dockray GJ. Expression of cannabinoid CB1 receptors by vagal afferent neurons is inhibited by the cholecystokinin. J Neurosci 2004;24:27082715 .

52. Burdyga G, Lal S, Spiller D, et al. Localization of orexin-1 receptors to vagal afferent neurons in the rat and humans. Gastroenterology 2003;124:129-139.

53. Burdyga G, Varro A, Dimaline R, Thompson DG, Dockray GJ. Feeding-dependent depression of melanin-concentrating hormone and melanin-concentrating hormone receptor-1 expression in vagal afferent neurones. Neuroscience 2006;137:1405-1415.

54. Date Y, Toshinai K, Koda S, et al. Peripheral interaction of ghrelin with cholecystokinin on feeding regulation. Endocrinology 2005; 146:3518-3525

55. De Lartigue G, Dimaline R, Varro A, Dockray GJ. Cocaine- and amphetamine-regulated transcript: stimulation of expression in rat vagal afferent neurons by cholecystokinin and suppression by ghrelin. J Neurosci 2007;27:2876-2882.

56. Moran TH, Katz LF, Plata-Salaman CR, Schwartz GJ. Disordered food intake and obesity in rats lacking cholecystokinin A receptors. Am J Physiol 1998;274(3 Pt 2):R618-R625.

57. Nakamura H, Kihara Y, Tashiro M, et al. Defects of cholecystokinin (CCK)-A receptor gene expression and CCK-A receptormediated biological functions in Otsuka Long-Evans Tokushima Fatty (OLETF) rats. J Gastroenterol 1998;33:702-709.

58. Miller LJ, Holicky EL, Ulrich CD, Wieben ED. Abnormal processing of the human cholecystokinin receptor gene in association with gallstones and obesity. Gastroenterology 1995;109:1375-1380.

59. Schneider H, Sänger P, Hanisch E. In vitro effects of cholecystokinin fragments on human gallbladders. Evidence for an altered CCK-receptor structure in a subgroup of patients with gallstones. J Hepatol 1997;26:1063-1068.

60. Campfield LA, Smith FJ, Guisez Y, Devos R, Burn P. Recombinant mouse $\mathrm{OB}$ protein: evidence for a peripheral signal linking adiposity and central neural networks. Science 1995;269:546-549.

61. Halaas JL, Gajiwala KS, Maffei M, et al. Weight-reducing effects of the plasma protein encoded by the obese gene. Science 1995;269: 543-546.

62. Loftus TM. An adipocyte-central nervous system regulatory loop in the control of adipose homeostasis. Semin Cell Biol 1999;10:11-18.

63. Considine RV, Sinha MK, Heiman ML, et al. Serum immunoreactiveleptin concentration in normal weight and obese humans. $\mathrm{N}$ Engl J Med 1996;334:292-295.

64. Robertson SA, Leinninger GM, Myers MG Jr. Molecular and neural mediators of leptin action. Physiol Behav 2008;94:637-642.

65. Zhang Y, Proenca R, Maffei M, Barone M, Leopold L, Friedman JM. Positional cloning of the mouse obese gene and its human homologue. Nature 1994;372:425-432.

66. Bado A, Levaseur S, Attoub S, et al. The stomach is a source of leptin. Nature 1998;394:790-793.

67. Sobhani I, Bado A, Vissuzaine C, et al. Leptin secretion and leptin receptor in the human stomach. Gut 2000;47:178-183.

68. Pelleymounta MA, Cullon MJ, Baker MB, et al. Effects of the obese gene product on body weight regulation in ob/ob mice. Science 1995;269:540-543.

69. Levin N, Nelson C, Gurney A, Vandlen R, de Sanvege F. Decreased food intake does not completely account for adiposity reduction after ob protein infusion. Proc Natl Acad Sci USA 1996; 93:1726-1730.

70. Chen G, Koyama K, Yuan X, et al. Disappearance of body fat in normal rats induced by adenovirus-mediated leptin gene therapy. Proc Natl Acad Sci USA 1996;93:14795-14799.

71. Barachina MD, Martínez V, Wei JY, Taché Y. Leptin-induced decrease in food intake is not associated with changes in gastric emptying in lean mice. Am J Physiol 1997;272(3 Pt 2):R1007-R1011.

72. Yuan CS, Dey L, Xie JT, Aung HH. Gastric effects of galanin and its interaction with leptin on brainstem neuronal activity. J Pharmacol Exp Ther 2002;301:488-493.

73. Moran TH, Ameglio PJ, Schwartz GJ, McHugh PR. Blockade of type $A$, not type $B$, CCK receptors attenuates satiety actions on exogenous and endogenous CCK. Am J Physiol 1992;262(Pt 2):R46-R50

74. Ritta RC, Covasa M, Matson CA. Cholecystokinin: proofs and prospects for involvement in control of food intake and body weight. Neuropeptides 1999;33:387-399.

75. Schwartz MW, Woods SC, Porte D Jr, Seeley RJ, Baskin DG Central nervous system control of food intake. Nature 2000;404: 661-671.

76. Cowley MA, Smart JL, Rubinstein M, et al. Leptin activates anorexigenic POMC neurons through a neural network in the arcuate nucleus. Nature 2001;411:480-484.

77. Kievit P, Howard JK, Badman MK, et al. Enhanced leptin sensitivity and improved glucose homeostasis in mice lacking suppressor of cytokine signaling-3 in POMC-expressing cells. Cell Metabolism 2006;4:123-132.

78. Obici S, Feng Z, Tan J, Liu L, Karkanias G, Rossetti L. Central melanocortin receptors regulate insulin action. J Clin Invest 2001; 108:1079-1085

79. Dungan HM, Clifton DK, Steiner RA. Minireview: kisspeptin neurons as central processors in the regulation of gonadotropin-releasing hormone secretion. Endocrinology 2006;147:1154-1158.

80. Rondini TA, Baddini SP, Sousa LF, Bittencourt JC, Elias CF. Hypothalamic cocaine- and amphetamine-regulated transcript neurons project to areas expressing gonadotropin releasing hormone immunoreactivity and to the anteroventral periventricular nucleus in male and female rats. Neuroscience 2004;125:735-748.

81. Harris M, Aschkenasi C, Elias CF, et al. Transcriptional regulation of the thyrotropin-releasing hormone gene by leptin and melanocortin signaling. J Clin Invest 2001;107:111-120.

82. Elmquist JK, Coppari R, Balthasar N, Ichinose M, Lowell BB. Identifying hypothalamic pathways controlling food intake, body weight, and glucose homeostasis. J Comp Neurol 2005;493:63-71.

83. Morton GJ, Cummings DE, Baskin DG, Barsh GS, Schwartz 
MW. Central nervous system control of food intake and body weight. Nature 2006;443:289-295.

84. Elmquist JK, Elias CF, Saper CB. From lesions to leptin: hypothalamic control of food intake and body weight. Neuron 1999;22: 221-232.

85. Elmquist JK, Bjørbaek C, Ahima RS, Flier JS, Saper CB. Distributions of leptin receptor mRNA isoforms in the rat brain. J Comp Neurol 1998;395:535-547.

86. Baskin DG, Schwartz MW, Seeley RJ, et al. Leptin receptor long-form splice-variant protein expression in neuron cell bodies of the brain and co-localization with neuropeptide Y mRNA in the arcuate nucleus. J Histochem Cytochem 1999;47:353-362.

87. Marsh DJ, Hollopeter G, Huszar D, et al. Response of melanocortin-4 receptor-deficient mice to anorectic and orexigenic peptides. Nat Genet 1999;21:119-122.

88. Ste Marie L, Miura GI, Marsh DJ, Yagaloff K, Palmiter RD. A metabolic defect promotes obesity in mice lacking melanocortin-4 receptors. Proc Natl Acad Sci USA 2000;97:12339-12344.

89. Bates $\mathrm{SH}$, Stearns WH, Dundon TA, et al. STAT3 signaling is required for leptin regulation of energy balance but not reproduction. Nature 2003;421:856-859.

90. Björnholm M, Münzberg H, Leshan RL, et al. Mice lacking inhibitory leptin receptor signals are lean with normal endocrine function. J Clin Invest 2007;117:1354-1360.

91. Gao Q, Wolfgang MJ, Neschen S, et al. Disruption of neural signal transducer and activator of transcription 3 causes obesity, diabetes, infertility, and thermal dysregulation. Proc Natl Acad Sci USA 2004;101:4661-4666.

92. Bjorbak C, Lavery HJ, Bates SH, et al. SOCS3 mediates feedback inhibition of the leptin receptor via Tyr985. J Biol Chem 2000; 275:40649-40657.

93. Gill HJ. Distributed neural control of energy balance: contributions from hindbrain and hypothalamus. Obesity (Silver Spring) 2006; 14(suppl 5):216S-221S.

94. Buyse M, Ovesjö ML, Goïot H, et al. Expression and regulation of leptin receptor proteins in afferent and efferent neurons of the vagus nerve. Eur J Neurosci 2001;14:64-72.

95. Peiser C, Springer J, Groneberg DA, McGregor GP, Fischer A, Lang RE. Leptin receptor expression in nodose ganglion cells projecting to the rat gastric fundus. Neurosci Lett 2002;320:41-44.

96. Li Y, Wu X, Zhou S, Owyang C. Low-affinity CCK-A receptors are coexpressed with leptin receptors in rat nodose ganglia: implications for leptin as a regulator of short-term satiety. Am J Physiol Gastrointest Liver Physiol 2011;300:G217-G227.

97. Wang YH, Taché Y, Sheibel AB, Go VL, Wei JY. Two types of leptin-responsive gastric vagal afferent terminals: an in vitro single-unit study in rats. Am J Physiol 1997;273(2 Pt 2):R833-R837.

98. Emond M, Schwartz GJ, Ladenhiem EE, Moran TH. Central leptin modulates behavioral and neural responsitivity to CCK. Am J Physiol 1999;276(5 Pt 2):R1545-R1549.

99. Matson CA, Ritter RC. Long-term CCK-leptin synergy suggests a role for CCK in the regulation of body weight. Am J Physiol 1999;276(4 Pt 2):R1038-R1045.

100. Matson CA, Reid DF, Cannon TA, Ritter RC. Cholecystokinin and leptin act synergistically to reduce body weight. Am J Physiol Regul Integr Comp Physiol 2000;278:R883-R890.

101. Yuan CS, Attele AS, Dey Z, Xie JT. Gastric effects of cholecystokinin and its interaction with leptin on brainstem neuronal activity in neonatal rats. J Pharmacol Exp Ther 2000;295:177-182.

102. White DW, Wang DW, Chua SC Jr, et al. Constitutive and impaired signaling of leptin receptors containing the Gln $\rightarrow$ Pro extracellular domain fatty mutation. Proc Natl Acad Sci USA 1997; 94:10657-10662.

103. Niederau C, Meereis-Schwanke K, Klonowski-Stumpe H, Herberg L. CCK-resistance in Zucker obese vs lean rats. Regul Pept 1997; 70:97-104

104. Phillips MS, Liu Q, Hammond HA, et al. Leptin receptor missense mutation in the fatty Zucker rat. Nat Genet 1996;13:18-19.

105. Dryden S, King P, Packavance L, Doyle P, Williams G. Divergent effects of intracerebroventricular and peripheral leptin administration on feeding and hypothalamic neuropeptide $\mathrm{Y}$ in lean and obese (fa/fa) Zucker rats. Clin Sci (Lond) 1999;96:307-312.

106. De Fanti BA, Backus RC, Hamilton JS, Gietzen DW, Horwitz BA. Lean $(\mathrm{Fa} / \mathrm{Fa})$ but not obese ( $\mathrm{fa} / \mathrm{fa})$ Zucker rats release cholecystokinin at PVN after a gavaged meal. Am J Physiol 1998;275(1 Pt 1):E1-E5.

107. Zhang X, Wrzeszczynska MH, Horvath CM, Darnell JE Jr. Interacting regions in Stat 3 and c-Jun that participate in cooperative transcriptional motivation. Mol Cell Biol 1999;19:7138-7146.

108. Covasa M, Ritter RC. Rats maintained on high-fat diets exhibit reduced satiety in response to CCK and bombesin. Peptides 1998;19: 1407-1415.

109. French SJ, Murray B, Rumsey RD, Fadzlin R, Read NW. Adaptation to high-fat diets: effects on eating behavior and plasma cholecystokinin. Br J Nutr 1995;73:179-189.

110. Cunningham KM, Daly J, Horowitz M, Read NW. Gastrointestinal adaptation to diets of differing fat composition in human volunteers. Gut 1991;32:483-486.

111. Covasa M, Ritter RC. Reduced sensitivity to the satiation effect of intestinal oleate in rats adapted to high-fat diet. Am J Physiol 1999; 277(1 Pt 2):R279-R285.

112. De Lartigue G, Barbier de la Serre C, Espero E, Lee J, Raybould HE. Diet-induced obesity leads to the development of leptin resistance in vagal afferent neurons. Am J Physiol Endocrinol Metab 2011;301:E187-E195. 